\title{
Myenteric neuronal plasticity induced by Toxoplasma gondii (genotype III) on the duodenum of rats
}

\author{
RODRIGO M. PAPAZIAN-CABANAS ${ }^{1}$, EDUARDO J.A. ARAÚJO ${ }^{2}$, \\ ARISTEU V. DA SILVA ${ }^{3}$ and DÉBORA M.G. SANT'ANA ${ }^{4,5}$ \\ ${ }^{1}$ Universidade Paranaense (UNIPAR), Praça Mascarenhas de Moraes, 4282, Centro, 87502-210 Umuarama, PR, Brasil \\ ${ }^{2}$ Universidade Estadual de Londrina (UEL), Centro de Ciências Biológicas, \\ Departamento de Histologia, Caixa Postal 6001, 86051-980 Londrina, PR, Brasil \\ ${ }^{3}$ Universidade Estadual de Feira de Santana (UEFS), Departamento de Ciências Biológicas, \\ Rodovia Transnordestina, s/n, Novo Horizonte, 44036-900 Feira de Santa, BA, Brasil \\ ${ }^{4}$ Programa de Pós-Graduação em Biociências Aplicadas à Farmácia (PBF), \\ Avenida Colombo, 5790, (BCE), 87900-020 Maringá, PR, Brasil \\ ${ }^{5}$ Universidade Estadual de Maringá (UEM), Departamento de Ciências Morfológicas (DCM), \\ Avenida Colombo, 5790, Bloco O33, sala 108, 87900-020 Maringá, PR, Brasil
}

Manuscript received on December 20, 2010; accepted for publication on February 9, 2011

\begin{abstract}
The effects of acute and chronic infection caused by Toxoplasma gondii on duodenal myenteric neurons were analyzed. Eighteen rats were assigned into four groups: Acute Control Group (ACG, n=4); Acute Experimental Group (AEG, $n=4$ ); Chronic Control Group (CCG, $n=5$ ); and Chronic Experimental Group (CEG, $\mathrm{n}=5$ ). Rats from the AEG and CEG were inoculated orally with $10^{5}$ genotype III (BTU-II strain) tachyzoites of $T$. gondii isolated from a dog with neurological signs. Acute groups were killed after 24 hours after the inoculation and the chronic groups after 30 days. Whole-mount from the duodenum were stained with Giemsa. The population density of myenteric neurons, as well the body cell, nuclear and cytoplasmic area were analyzed. Both acute and chronic toxoplasmic infection did not provoke neuronal loss. On the other hand, plastic alterations were observed: decreasing of the nuclear and cytoplasmic area during the acute phase and neuronal hypertrophy during the chronic phase.
\end{abstract}

Key words: enteric nervous system, infection, parasite, toxoplasmosis.

\section{INTRODUCTION}

Toxoplasma gondii is an obligate intracellular protozoan, highly spread all over the world, which is responsible for an important zoonosis: toxoplasmosis. This disease is usually asymptomatic in humans; however, they are largely an accidental host. Domestic animals and livestock can be infected by this microorganism. In intermediate hosts (warm-

Correspondence to: Débora de Mello Gonçales Sant'Ana

E-mail:dmgsantana@gmail.com blooded vertebrates except felines), the parasite rapidly disseminates throughout the body, right after the infection, by fast growing tachyzoites. In response to following immune responses, T. gondii differentiates into a slow-growing tissue stage named bradyzoites, which inhabit in tissue cysts within lower-turnover cells (Weiss and Kim 2007). For this reason, neurons are normally encysted by this parasite, which explains the severe neurological disorders observed in immunecompromised patients. 
In addition, when $T$. gondii invades the host cell, it is known that a parasitophorus vacuole (PV) is formed, which has a membrane containing proteins (ROP2) anchoring the mitochondria of the host cell to the PV. This strategy contributes for the lysosome of the host cells not to merge with the PV in order to protect the intracellular development of the bradyzoites (Sinai and Joiner 2001). Therefore, cells with higher number of mitochondria (such as neurons) seem to be the primary target of this protozoan.

Besides, studies reported changes in the intestinal wall of infected animals (Shiraishi et al. 2009, Bonapaz et al. 2010, Da Silva et al. 2010a, b), possibly because the digestive tube is the route of entry of T. gondii (Weiss and Kim 2007). Such changes indicate the both digestion and absorption may be compromised, even in animals showing no clinical signs of infection. Additionally, the literature relates diarrhea in animals (Weiss and Kim 2007, Galli et al. 2008, Odorizzi et al. 2010), which indicates that the enteric nervous system (ENS) - the main autonomic nervous system subdivision that controls the digestive function - can be altered by the toxoplasmic infection.

Experiments carried out by our group demonstrated that the myenteric plexus - from rats infected with the same $T$. gondii strain (BTU-II / genotype III) - shows different alterations depending of the analyzed region from the intestine. Thus, it is known for this strain that, during the acute phase, hypertrophy in the jejunal neurons (R.P. Torres et al., unpublished data), atrophy in those from the ileum and the colon, respectively (Sugauara et al. 2008). On the other hand, in the chronic phase, no morphometric alterations in the jejunal myenteric neurons (R.P. Torres et al., unpublished data), and atrophy and hypertrophy in those from the ileum and the colon, respectively (Sugauara et al. 2008). It is perceptible that the effects of acute and chronic infection caused by the BTU-II strain of T. gondii (genotype III) for the duodenal myenteric plexus of rats, and this was the objective of this study.

\section{MATERIALS AND METHODS}

This experimental protocol was previously approved by the Ethics Committee for Animal Experimentation of Univesidade Paranaense in accordance with the norms of Colégio Brasileiro de Experimentação Animal (COBEA). It also meets the orientations presented on the NRC Guide for the Care and Use of Laboratory Animals.

EXPERIMENTAL OUTLINE

For this fully randomized study, eighteen male 60-day-old Wistar rats $(266.25 \pm 21.76 \mathrm{~g})$ were used. They were assigned into four groups: Acute Control Group (ACG, $\mathrm{n}=4$ ), Acute Experimental Group (AEG, n=4), Chronic Control Group (CCG, n=5), and Chronic Experimental Group (CEG, $\mathrm{n}=5) . \mathrm{NaCl}$ solution was administered through gavage to the animals in the ACG and CCG. T. gondii tachyzoites $\left(10^{4}\right)$ from a genotype III (BTU-II) strain isolated from dog brains with neurological symptomatology (Da Silva et al. 2005) were orally administered to the AEG and CEG.

EUthanASIA AND COLLECTION OF BIOLOGICAL MATERIAL

Acute groups were died after 24 hours, and the chronic groups after 30 days. In this moment, the animals were weighted and anesthetized by the intramuscular route using following protocol: $2 \%$ Acepromazine $(1.26 \mathrm{~mL} / \mathrm{kg})+10 \%$ Ketamine $(1.26$ $\mathrm{mL} / \mathrm{kg})+2.5 \%$ Xylazine hydrochloride $(0.42 \mathrm{~mL} /$ $\mathrm{kg})$, and $1 \%$ Atropine sulfate $(0.22 \mathrm{~mL} / \mathrm{kg})$. Blood samples were collected by puncturing the retroorbital plexus of each animal of the chronic groups, and then used in serological analysis for antibodies against $T$. gondii by the direct agglutination method (Da Silva et al. 2002). All animals were died by anesthetic deepening, followed by laparotomy for the removal of the duodenum. 
Obtaining the Whole-Mount Preparations

Theses intestinal segments were measured with respect to length using a milimetric ruler. Then, washed in a $9 \%-\mathrm{NaCl}$ solution, filled and immersed in a fixation solution containing acetic formol for 48h. The duodenal samples were inspected for gross pathology lesions. Next, they were dissected with the aid of a stereomicroscope by removing the mucosa and the submucosa. Therefore, the whole-mount used for this study were constituted by the external muscle (where the myenteric plexus is located), which was stained according to the Giemsa technique (Barbosa 1978).

\section{QUANTITATIVE ANALYSIS}

Duodenum of all animals was divided in three regions for morphometric and quantitative analysis: mesenteric $\left(0^{\circ}-60^{\circ} ; 300^{\circ}-360^{\circ}\right)$, antimesenteric $\left(120^{\circ}\right.$ $\left.240^{\circ}\right)$, and intermediate region $\left(60^{\circ}-120^{\circ} ; 240^{\circ}-300^{\circ}\right)$ considering the mesenteric insertion as $0^{\circ}$. A MOTIC BL220A binocular microscope with a 40x objective was used in order to count neurons in 40 microscopic fields $\left(0.21 \mathrm{~mm}^{2}\right)$ of each region (mesenteric, antimesenteric and intermediate), totalizing $25.2 \mathrm{~mm}^{2}$ per animal. Neurons positioned at the edges of each field were counted in alternated fields.

\section{MORPHOMETRIC ANALYSIS}

The area of the body cell, cytoplasm and nucleus of 300 myenteric neurons (100 cells per region: mesenteric, antimesenteric and intermediate) from each intestinal segment collected (uniformly distributed around the intestinal circumpherence) was measured with software: Image Motic Plus, version 2.0. A microscope with a digital camera (Moticam 2000, 2.0 megapixel) attached to a computer was used. From these values, the neurons were assigned into classes considering the body cell area $\left(50 \mu \mathrm{m}^{2}\right.$ intervals $)$ and the nucleus/body cell area ratio (0.05 intervals).

\section{STATISTIC ANALYSIS}

All data were initially submitted to the KolmogorovSmirnov test for the verification of their distribution type. Normal distribution data were expressed as mean \pm standard deviation, and dates with free distribution were expressed as median and percentiles 25 and 75 (P25; P75). The ANOVA one-way (data presenting normal distribution) and Kruskal-Wallis (data presenting free distribution) were used in order to compare the groups, by considering $\mathrm{p}<0.05$ significant values.

\section{RESULTS}

Animals from the CEG were positive in serological analysis for antibodies anti- $T$. gondii. None of the rats showed diarrhea during the experiment nor pathological lesions were detected during inspection. No significant differences were observed in the body weight and duodenum length of rats in any of the groups (Table I). The neuronal quantitative analysis did not demonstrate alterations (Table II), and the staining technique used did not allow us to found tachyzoites or bradyzoites of $T$. gondii inside the neurons.

The acute infection provoked enlargement of the body cell and reduction of the nuclear and cytoplasm area of myenteric neurons. Additionally, it was observed that the enlargement of the cytoplasmic area and the preservation of the nuclear

TABLE I

Mean \pm standard deviation of the body weight and duodenum length of rats from control (ACG and CCG) and experimental (AEG and CEG) groups infected by genotype III (BTU-II strain) tachyzoites of Toxoplasma gondii.

\begin{tabular}{ccc}
\hline Group & Weight $(\mathrm{g})$ & Duodenal length $(\mathrm{cm})$ \\
\hline ACG & $219.33 \pm 16.74$ & $9.000 \pm 0.000$ \\
AEG & $227.07 \pm 16.25$ & $7.875 \pm 0.629$ \\
CCG & $368.30 \pm 16.83$ & $6.800 \pm 1.090$ \\
CEG & $368.30 \pm 16.83$ & $6.800 \pm 1.710$ \\
\hline
\end{tabular}

There is no significant difference between control and experimental groups $(\mathrm{p}>0.05)$. 
TABLE II

Median (percentil 25 and 75) of the number of duodenal myenteric neurons in $25.2 \mathrm{~mm} 2$, body cell area, nuclear area, cytoplasmic area, and the ratio between the nuclear and the body cell area of duodenal myenteric neurons of rats from control (ACG and CCG) and experimental (AEG and CEG) groups infected by genotype III (BTU-II strain) tachyzoites of Toxoplasma gondii.

\begin{tabular}{cccccc}
\hline Group & $\begin{array}{c}\text { Number of neurons } \\
\left(\text { in } 25.2 \mathrm{~mm}^{2}\right)\end{array}$ & $\begin{array}{c}\text { Body cell area } \\
\left(\mu \mathrm{m}^{2}\right)\end{array}$ & $\begin{array}{c}\text { Nucleous area } \\
\left(\mu \mathrm{m}^{2}\right)\end{array}$ & $\begin{array}{c}\text { Cytoplasm area } \\
\left(\mu \mathrm{m}^{2}\right)\end{array}$ & $\begin{array}{c}\text { Nucleous/body } \\
\text { cell ratio }\end{array}$ \\
\hline \multirow{2}{*}{ ACG } & 2013.5 & $242.4^{*}$ & $89.9^{*}$ & $172.10^{*}$ & $0.34^{*}$ \\
& $(1584.5 ; 2255.0)$ & $(223.9 ; 306.6)$ & $(75.7 ; 104.6)$ & $(144.2 ; 205.5)$ & $(0.31 ; 0.38)$ \\
AEG & 2368.0 & $228.2^{*}$ & $72.3^{*}$ & $159.65^{*}$ & $0.31^{*}$ \\
& $(1533.0 ; 3387.5)$ & $(189.5 ; 272.7)$ & $(60.8 ; 84.2)$ & $(128.0 ; 197.2)$ & $(0.27 ; 0.35)$ \\
CCG & 3530.0 & $183.1^{*}$ & 55.9 & $125.70^{*}$ & $0.31^{*}$ \\
& $(3470.0 ; 3752.9)$ & $(151.8 ; 218.6)$ & $(47.1 ; 67.1)$ & $(101.0 ; 154.9)$ & $(0.27 ; 0.35)$ \\
CEG & 3331.0 & $197.0^{*}$ & 56.4 & $139.50^{*}$ & $0.29^{*}$ \\
& $(3110.0 ; 3392.0)$ & $(158.6 ; 242.3)$ & $(47.4 ; 66.4)$ & $(107.7 ; 176.2)$ & $(0.25 ; 0.32)$ \\
\hline
\end{tabular}

Values presented as median (P25; P75). Values in the same column are significantly different $(\mathrm{p}<0.05)$.

area resulted in the increasing of the body cell area, during the chronic infection (Table II). It should be remarked that specific alterations were observed only in the acute infection: (1) when the distribution of neurons according to different classes of body cell size was evaluated, an increased prevalence of smaller neurons (151-200 $\left.\mu \mathrm{m}^{2}\right)$ and a reduced prevalence of larger cells $\left(301-350 \mu \mathrm{m}^{2}\right)$ was detected (Figure 1); (2) with relation to the nuclear area, animals from the AGE showed an increasing number of neurons in which the nucleus took 26 to $30 \%$ of the body cell, and a reduction in the number of those in which the nucleus took more than $36 \%$ of the body cell (Figure 2).

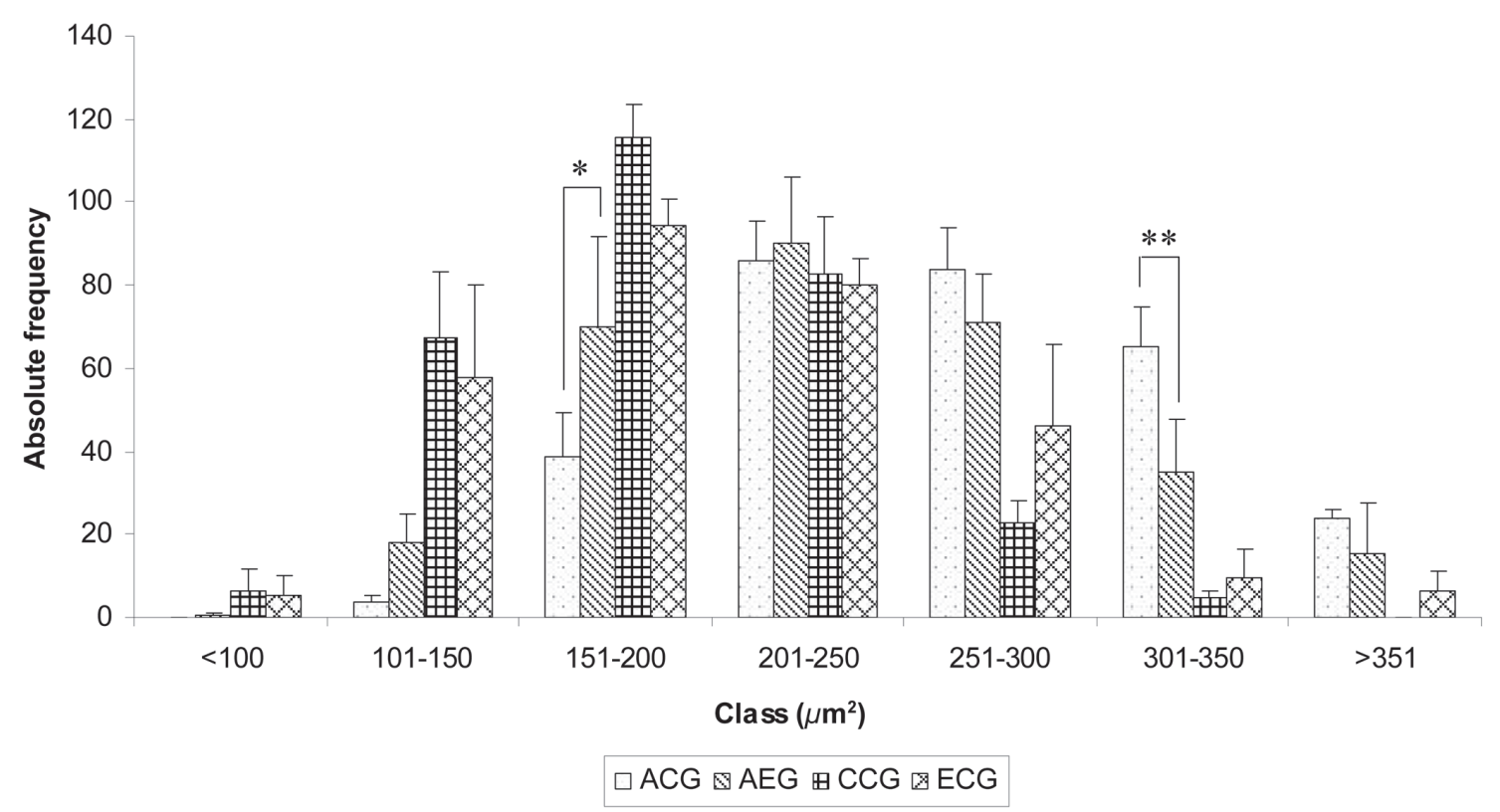

Figure 1 - Histogram of the body cell area of duodenal myenteric neurons of rats from control (ACG and CCG) and experimental (AEG and CEG) groups infected by genotype III (BTU-II strain) tachyzoites of Toxoplasma gondii. Columns of the same class with one asterisco $(* \mathrm{p}<0.05)$ and with two asteriscos $(* * \mathrm{p}<0.01)$ are significantly different. 


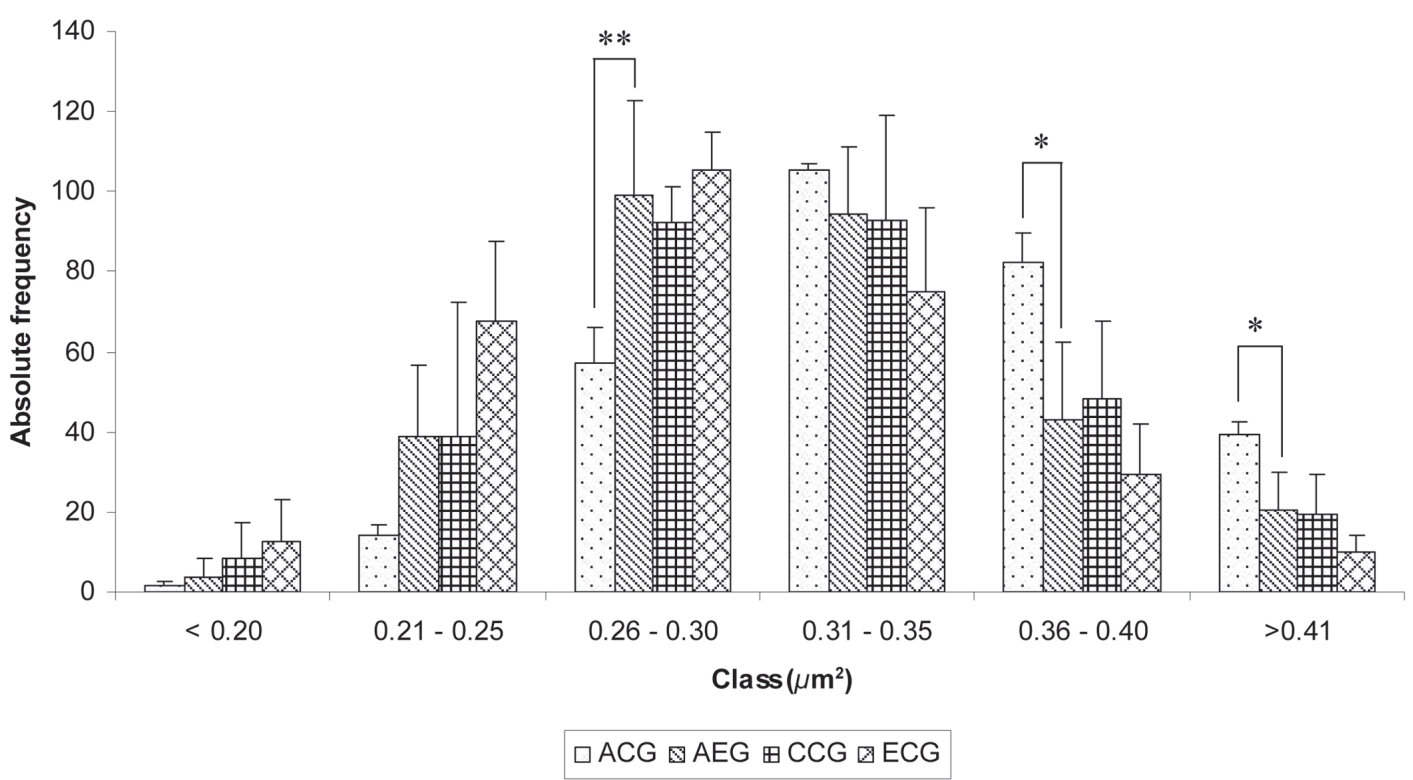

Figure 2 - Histogram of the nucleus/body cell ratio of duodenal myenteric neurons of rats from control (ACG and CCG) and experimental (AEG and CEG) groups infected by genotype III (BTU-II strain) tachyzoites of Toxoplasma gondii. Columns of the same class with one asterisco $\left({ }^{*} \mathrm{p}<0.05\right)$ and with two asteriscos $(* * \mathrm{p}<0.01)$ are significantly different.

\section{DISCUSSION}

Only animals from the CEG showed positive serology for $T$. gondii, demonstrating the efficiency of the experimental model used in this study to induce the toxoplasmic infection. The strain is one of the most important factors to determine the infectivity and pathogenicity of the parasite (Dubey 1996). Although using a genotype III strain - considered of low infectivity when compared to genotype I strains (Howe et al. 1997) - it was effectively infective.

It is possible consider that the infection was caused by a small number of infective forms once tachyzoites showed low infectivity after gastric digestion, demonstrating low resistance to pepsin (Dubey 1998). However, not all tachyzoites were killed by gastric juice once the presence of antibodies by serological analysis, demonstrating that infection occurred.

T. gondii can cause diarrhea on dogs, chickens, pigs (Freyre and Falcon 1989), rodents (Dubey and Frenkel 1973) and immunocompromised humans
(Boothroyd and Grigg 2002), with intestinal ulcers evolving to lethal ileitis in mice (Mennechet et al. 2002). However, neither diarrhea nor gross pathology lesions were observed in this study. These results indicate that, although the experimental model used in this study was enough to induce infectivity, the pathogenicity was low. By this way, no changes in the body weight and duodenum length and the absence of disease signs both in the chronic and acute phases of the infection.

Other studies of this same research group using the same experimental conditions showed a reduction of the jejunum-ileum area (R.P. Torres et al., unpublished data) and of the length and width of terminal ileum (Sugauara et al. 2008) caused possibly by atrophy or hypoplasia of the organ. Therefore, comparisons between organ areas obtained in previous and in this study show how singular organs respond differently to toxoplasmic infection.

The duodenum is a short organ with $\mathrm{pH}$ 6.6, while $\mathrm{pH}$ in other parts of the small intestine ranges from 6.9 to 7.5 (Guyton and Hall 2002). The Brünner glands located in the submucosa of 
this organ are responsible for the production of a thick mucus layer that covers its internal surface. Therefore, the lower $\mathrm{pH}$ and the thick mucus layer may have made it difficult for the parasite to gain access to the enterocytes, reducing in this way the number of microorganisms available to cause direct and indirect lesions.

Alterations were not detected in quantitative analysis of myenteric neurons. Other studies of this same research group also demonstrated that the number of myenteric neurons remains constant in rats infected with $T$. gondii, no matter the duration of the infection, the strain used or the organ studied (Sugauara et al. 2008, 2009, Barbosa et al. 2009, Soares et al. 2009, Pereira et al. 2010). On other hand, in a parallel study during the chronic phase of the toxoplasmic infection, R.P. Torres et al. (unpublished data) observed a reduction of the jejunum-ileum without proportionally greater myenteric neuronal density, reporting a $17.54 \%$ reduction in the neuronal population. In the present study, as there was no reduction in intestinal area, the maintenance of density demonstrates that these neurons did not die due to infection. Would duodenal myenteric neurons be protected from the toxoplasmic infection?

Tachyzoites or tissue cysts of $T$. gondii were not detected inside the neurons. It is well known that, during the acute infection, parasitemia is observed after the parasite penetration in the organism, and immunity is activated followed by the formation of cysts in different tissues (Frenkel et al. 1975). Cysts characterize the chronic infection persisting from months to years and sometimes throughout the lifetime of the host. In parallel with the production of tissue cysts parasitemia gradually decreases and disappears, not been found in the blood of rats after 60 days of infection possibly due to macrophage activity characterizing a natural resistance of rats (Guerrero 1995). During the chronic phase of infection, tissue cysts are commonly found in nervous tissue (Guerrero and Chinchilla
1996), however, it is not common to find them in histological sections (De Champs et al. 1998). The absence of tissue cysts in the present study may indicate their low prevalence in the enteric nervous system, possibly due to a series of factors such as the resistance of rats (Guerrero 1995) and the resistance of neurons (Lüder-Carsten et al. 1999).

After ingestion of the parasite, T. gondii penetrates the epithelial cells of the intestine, being able to reach different organs such as the liver and the heart in only few hours after infection (Barragan and Sibley 2003). In this way, the immune system quickly responds inducing an answer characterized by the differentiation of a T-cell subpopulation called $\mathrm{T}_{\mathrm{h}} 1$. Differentiation of CD4 T-cells is activated by antigens of $T$. gondii in $T_{h} 1$ effector cells ${ }^{22}$. When toxoplasmosis ensues, the parasite binds to receptors on macrophages and dendritic cells stimulating rapid production of IL12 cytokine, essential for the stimulated production of IFN- $\gamma$. Rapid induction of IL-12 production by the protozoan may contribute for the control of multiplication and diminishing of virulence (Robben et al. 2004). This may be one of the reasons why the number of enteric neurons in the present study was preserved.

Although plastic responses induced by $T$. gondii in myenteric neurons have already been described (Sugauara et al. 2008, 2009, Barbosa et al. 2009, Soares et al. 2009, Odorizzi et al. 2010, Pereira et al. 2010), our results demonstrate that these cells did not undergo significant changes, suggesting that duodenal myenteric neurons are more resistant to infection or are less accessible to pathogens. Therefore, in order to prove this hypothesis further studies using different strains and techniques and studies upon the cells involved in this process are necessary.

There are evidences that the nervous system of different species may show diverse responses to infection by tachyzoites of $T$. gondii (Halonen et al. 1996). In studies using nervous cells from the brain cortex of rats was proved that neurons and astrocytes 
are the main host cells involved in the intracerebral proliferation phase (when tachyzoites are observed), and that the microglial cells inhibit parasite growth, having toxoplasmicidal activity, hence, the propagation of $T$. gondii in the CNS is reduced (Lüder-Carsten et al. 1999). As myenteric ganglia do not have microglial cells, the protection of the nervous system located inside the intestinal wall depends on the immune cells found in this organ (Furness 2006).

Even though neuronal death was not observed, they may have been affected by infection responding with changes in size to the direct stimulation by the parasite or to the indirect stimulation by inflammatory cytokines. These changes were probably a reflex of modifications in cell metabolism. During the acute phase of infection the nuclear area was reduced and the body cell area enlarged. These findings revealed that acute infection may have repressed the synthesis of nuclear and cytoplasmatic proteins leading to cell volume changes, probably indicating cell injury as described by Sugauara et al. (2008, 2009). It was demonstrated that the jejunal myenteric neurons presented enlargement of the body cell area, nuclear area, and cytoplasm area, which was attributed to an acceleration of cytoplasmatic and nuclear metabolism (R.P. Torres et al., unpublished data), probably induced by intracellular $T$. gondii growth which depends on the increasing of the cell metabolism in the host (Carruthers and Suzuki 2007) or by the indirect action of inflammatory cytokines.

In the chronic phase was observed that the body cell and the cytoplasmic area were enlarged, whereas the nuclear area was preserved, indicating that duodenal infection influenced the metabolism of these neurons. Therefore, the interaction between the parasite and the myenteric cell components needs to be further investigated. In previous studies with jejunum and ileum using different strains under chronic infection, results were different from those found in the duodenum. In these studies a reduction of the nuclear and neuronal areas was observed (Sugauara et al. 2008, R.P. Torres et al., unpublished data).
When the neuron frequency assigned into classes according to the body cell area was analyzed most of the cells were concentrated in the classes between 151 and $300 \mu \mathrm{m}^{2}$, in both the control and the experimental group. When the consequences of infection on this distribution, changes were only observed in the acute phase of the experiment in which the prevalence of neurons increased between the classes 151-200 $\mu \mathrm{m}^{2}(\mathrm{p}<0.05)$, and decreased between the classes $301-350 \mu \mathrm{m}^{2}(\mathrm{p}<0.01)$.

In concern about the distribution of frequency considering the nucleus/body cell area ratio, most of neurons of all groups had nuclei that took from 26 to $35 \%$ of the body cell, whereas in the acute infection there was a significant increasing in the number of neurons in the classes between 0.26-0.30, and a reduction in the prevalence of neurons in the classes between 0.36-0.40 $(p<0.05)$, and $>0.41 \quad(p<0.05)$. However, further studies using transmission electron microscopy are necessary in order to elucidate which cell element induced morphometric alterations in enteric neurons infected by $T$. gondii.

In the present study was demonstrated that the acute and chronic infection caused by genotype III tachyzoites of Toxoplasma gondii did not provoked alterations in the number of myenteric neurons, but induced to plastic changes such as decreasing of the nuclear and cytoplasmic area during the acute phase and neuronal hypertrophy on duodenum of rats.

\section{ACKNOWLEDGMENTS}

The authors thank Universidade Paranaense (UNIPAR) for the financial support.

\section{RESUMO}

Foram analisados os efeitos da infecção aguda e crônica provocada pelo Toxoplasma gondii sobre os neurônios mientéricos do duodeno. Dezoito ratos foram divididos em quatro grupos: Grupo Controle Agudo (GCA, n=4), Grupo Experimental Agudo (GEA, n=4), Grupo Controle Crônico (GCC, n=5) e Grupo Experimental Crônico 
(GEC, $\mathrm{n}=5)$. Os animais do GEA e GEC receberam por via oral $10^{5}$ taquizoítos de Toxoplasma gondii da cepa BTUII (genótipo III) isolada de um cão com sintomatologia neurológica. Os grupos agudos foram submetidos à eutanásia após 24 horas e os crônicos após 30 dias da inoculação. Preparados totais do duodeno foram corados com Giemsa. A densidade populacional dos neurônios mientéricos, bem como a área do corpo celular, núcleo e citoplasma foram analisados. Ambas, as infecções toxoplásmicas aguda e crônica não provocaram a perda neuronal. Por outro lado, alterações plásticas foram observadas: diminuição da área nuclear e citoplasmática durante a fase aguda e hipertrofia neuronal durante a fase crônica.

Palavras-chave: sistema nervoso entérico, infecção, parasita, toxoplasmose.

\section{REFERENCES}

BARBOSA AJA. 1978. Técnica histológica para gânglios nervosos intramurais em preparados espessos. Rev Bras Pesq Med Biol 11: 95-97.

Barbosa BJP, AraúJo EJA, Da Silva AV and Sant'Ana DMG. 2009. Atrofia neuronal mientérica no íleo de ratos infectados cronicamente por uma cepa genótipo I de Toxoplasma gondii. Arq Cienc Vet Zool Unipar 12: 101-108.

BARRAGAN A AND SiBLEY D. 2003. Migration of Toxoplasma gondii across biological barriers. Trends Microbiol 11: 426-429.

Bonapaz RS, Hermes C, SANTOS FN, Da Silva AV, AraúJo EJA AND SANT'ANA DMG. 2010. Effects of infection with Toxoplasma gondii oocysts on the intestinal wall and the myenteric plexus of chicken (Gallus gallus). Pesq Vet Bras 30: 787-792.

Boothroyd JC AND GRIGG ME. 2002. Population biology of Toxoplasma gondii and its relevance to human infection: do different strains cause different disease? Curr Opin Microbiol 5: 438-442.

CARRUTHERS VB AND SUZUKI Y. 2007. Effects of Toxoplasma gondii infection on the brain Schizoph Bull 33: 745-751.

DA SiLvA AV, CUTOLO AA AND LANGONI H. 2002. Comparação da reação de imunofluorescência indireta e do método de aglutinação direta na detecção de anticorpos antiToxoplasma em soros de ovinos, caprinos, caninos, e felinos. Arq Inst Biol 69: 7-11.

Da Silva AV, Pezerico SB, Lima VY, Moretti LA, Pinheiro JP, TANAKA EM, RIBEIRO MG AND LANGONI H. 2005. Genotyping of Toxoplasma gondii strains isolated from dogs with neurologicas signs. Vet Parasitol 127: 23-27.

DA SiLVA JM, DA SILVA AV AND ARAÚJO EJA, SANT'ANADMG. 2010a. Efeitos da infecção crônica por Toxoplasma gondii sobre a parede intestinal de gatos domésticos. Rev Bras Parasitol Vet 19: 1-7.
Da Silva PC, Shiraishi CS, Da Silva AV, GonÇAlves GF, SANT'ANA DMG AND ARAÚJO EJA. 2010b. Toxoplasma gondii: a morphometric analysis of the wall and epithelial cells of pigs intestine. Exp Parasitol 125: 380-383.

De Champs C, Pelloux H, Dechelotte P, Giraud JC, Ball N AND AMBROISE-Thomas P. 1998. Toxoplasma gondii infection in rats by the RH strain: inoculum and age effects. J Parasitol 5: 215-218.

DUBEY JP. 1996. Pathogenicity and infectivity of Toxoplasma gondii oocysts for rats. J Parasitol 82: 951-956.

DUBEY JP. 1998. Structures of Toxoplasma gondii tachyzoites. bradyzoites. and sporozoites and biology and development of tissue cysts. Clin Microbiol 11: 294.

DUBEY JP AND FRENKEL JK. 1973. Experimental Toxoplasma infection in mice with strains producing oocysts. J Parasitol 59: 505-512.

FRENKEL JK, NELSON BM AND ARIAS-STELLA J. 1975. Immunosuppression and toxoplasmic encephalitis. Clinical and experimental aspects. Hum Pathol 6: 97-111.

FREYRE A AND FALCON JD. 1989. Toxoplasmosis y las espécies domésicas como zoonosis. Montevideo: Departamento de Publicaciones de La Universidad de la República, 322 p.

FURNESS JB. 2006. The enteric nervous system. Malden: Editora Blackwell Publishing, 274 p.

Galli S, BELINATO FC, LuCAS TM, DA SilVA RC, LONGONi H AND DA SILVA AV. 2008. Infecção experimental de frangos domésticos (Gallus gallus) com cepas geneticamente de Toxoplasma gondii. Vet Zootec 15: 400-606.

GUERRERO OM. 1995. Age influence in the natural resistance of white rat and mice to the protozoan Toxoplasma gondii. Rev Biol Trop 43: 27-30.

GUERRERO OM AND CHINCHILLA M. 1996. Toxoplasma gondii dissemination patterns in rats after oral infection with oocysts of an avirulent strain. Rev Biol Trop 44: 131-135.

GUYTON AC AND HALl JE. 2002. Tratado de fisiologia médica. Rio de Janeiro: Guanabara Koogan, 1264 p.

HALONEN WD, LYMAN AND CHIU FC. 1996. Growth and development of Toxoplasma gondii in human neurons and astrocytes. J Neuropathol Exp Neuro 55: 1150-1156.

Howe DK, Honore S, Derouin F AND Sibley DL. 1997. Determination of genotypes of Toxoplasma gondii strains isolated from patients with toxoplasmosis. J Clin Microbiol 35: 1411-1414.

LÜDER-CARSTEN GK, GIRALDO-VELÁSQUeZ M, SENDTNER M AND GROSS U. 1999. Toxoplasma gondii in primary rat CNS cells: differential contribution of neurons. astrocytes. and microglial cells for the intracerebral development and stage differentiation. Exp Parasitol 93: 23-32.

Mennechet FJD, Kasper LH, Rachinel N, Li W, VANDEWALLE A AND BUZONI-GATEL D. 2002. Lamina propria CD4+ T lymphocytes synergize with murine intestinal epithelia cells to enhance proinflammatory response against an intracellular pathogen. J Immunol 168: 2988-2996.

Odorizzi L, Moreira NM, GONÇALVES GF, DA Silva AV, SANT'ANA DMGAND ARAÚJO EJA. 2010. Quantitative and morphometric changes of subpopulations of myenteric neurons in swines with toxoplasmosis. Auton Neurosci 155: $68-72$. 
Pereira LS, DA SILVA AV, ARAÚJo EJA AND SANT'ANA DMG. 2010. Hypertrophy of NADH-diaphorase positive myenteric neurons in rat jejunum after acute infection caused by Toxoplasma gondii. J Venom Anim Toxins incl Trop Dis 16: 298-310.

Robben PM, Morgue DG, Truscott SM, TAKeda K, AKIRA S AND SiBleY D. 2004. Production of IL-12 by macrophages infected with Toxoplasma gondii depends on the parasite genotype. J Immunol 172: 3686-3694.

ShIRAISHI CS, DE AZEVEdo JF, DA Silva AV, SANT'ANA DMG AND ARAÚJO EJA. 2009. Análise morfométrica da parede intestinal e dinâmica de mucinas secretadas no íleo de frangos infectados por Toxoplasma gondii. Cienc Rural 39: 2146-2153.

SINAI AP AND JOINER KA. 2001. The Toxoplasma gondii protein ROP2mediates host organelle association with parasitophorus vacuole membrane. J Cell Biol 154: 95-108.
SoAres J, Moreira NM, DA Silva AV, SANT'ANA DMG AND ARAÚJO EJA. 2009. Infecção crônica por Toxoplasma gondii induzindo hipertrofia de neurônios do plexo mientérico do cólon descendente de Rattus norvegicus. Rev Bras Parasitol Vet 18: 57-60.

SugAuARA EYY, SANT'ANA DMG, ALMEIDA EC, REIS BA, DA SILVA AV AND ARAÚJO EJA. 2008. Alterations of the myenteric plexus of the ileum and the descending colon caused by Toxoplasma gondii (Genotype III). Arq Neuropsiquiatr 66: 516-523.

Sugauara EYY, Sant'Ana DMG, Da Silva AV, De Souza EA AND ARAÚJo EJA. 2009. Hypertrophy of the neurons in the ileum from rats infected with cysts of Toxoplasma gondii (Genotype II). Acta Sci Biol Sci 31: 195-201.

WeIss L AND KIM K. 2007. Toxoplasma gondii: The model apicomplexan. Perspectives and methods. Rio de Janeiro: Elsevier, $981 \mathrm{p}$. 